\title{
Biodegradation of Gasoline Polluted Soil Using Goat Dung
}

\author{
*1EGBEJA, TI; ${ }^{2}$ OGUCHE, JU; ${ }^{2}$ BASHIR, AA \\ ${ }^{l}$ Department of Animal and Environmental Biology, ${ }^{2}$ Department of Plant Science and Biotechnology, Faculty of Natural Sciences, Kogi \\ State University, P.M.B 1008, Anyigba, Kogi State, Nigeria \\ *Corresponding Author Email: Egbejati@ksu.edu.ng; Tel: +2348160373127
}

\begin{abstract}
Petroleum product leakages from underground storage tanks, distribution facilities and various industrial operations represent an important source of soil and aquifer contamination. This study was carried out to determine the effects of Goat Dung (GD) on Polycyclic Aromatic Hydrocarbon (PAH) degradation and microbiological composition. Top soil (0-15 cm depth) was collected from Nigerian National Petroleum Corporation Satellite Depot, Ejigbo, Lagos State. One kilogram of the gasoline polluted soil was measured into nine containers. The GD was mixed with the soil at the rate of 0,50 and $100 \mathrm{~g} \mathrm{~kg}^{-1}$ soil in triplicate and the containers were arranged in a Completely Randomized Design. Soil samples were taken from each container at 21 and 42 days for Hydrocarbon Utilizing Bacteria (HUB) and PAH determination using standard methods. Collected data were subjected to descriptive and inferential statistics. The HUB species identified were Bacillus, Staphylococcus, Klebsiella, Escherichia, Pseudomonas and Enterobacter. The PAH (mg $\mathrm{kg}^{-1}$ ) of the soil before GD application was 192.65. After the amendments at 0,50 and $100 \mathrm{~g} \mathrm{~kg}^{-1}$, this value reduced to $167.32 \pm 2.45,107.11 \pm 1.88$ and $75.10 \pm 3.65$, respectively at 21 days and $134.26 \pm 1.59,74.16 \pm 2.27$ and $46.14 .14 \pm 1.93$, respectively at 42 days. Biodegradation efficiency of $76 \%$ was recorded after 42 days in soil amended with $100 \mathrm{~g} \mathrm{~kg}^{-1}$ of GD. Application of $100 \mathrm{~g} \mathrm{~kg}^{-1}$ of GD was more effective in the remediation of PAH contaminated soil. Results demonstrated that GD could be used to enhance activities of the microbial hydrocarbon-degrading bacteria during bioremediation of gasoline polluted soil.
\end{abstract}

\section{DOI: https://dx.doi.org/10.4314/jasem.v23i8.25}

Copyright: Copyright $\mathbb{C} 2019$ Egbeja et al. This is an open access article distributed under the Creative Commons Attribution License (CCL), which permits unrestricted use, distribution, and reproduction in any medium, provided the original work is properly cited.

Dates: Received: 30 July 2019; Revised: 19 August 2019; 27 August 2019

Keywords: Biodegradation, Gasoline, Goat dung, Hydrocarbon, Pollution

Petroleum product leakages from underground storage tanks, distribution facilities and various industrial operations represent an important source of soil and aquifer contamination. Most of these petroleum products are complex mixture of normal, branched and cyclic alkanes, and aromatic compounds obtained from the middle-distillate fraction during petroleum separation (Gallego et al., 2001). Among several clean-up techniques available to remove petroleum hydrocarbons from the soil, biodegradation processes are gaining ground due to their simplicity, higher efficiency and cost-effectiveness when compared to other technologies like mechanical, burying, evaporation, dispersion, and soil washing (Alexander, 1994). Biodegradation processes rely on the natural ability of microorganisms to carry out the mineralization of organic chemicals, leading ultimately to the formation of carbon dioxide, water and biomass (Akpoveta et al., 2011). Amendment of soil with organic or inorganic nitrogen-rich nutrients in a process known as biostimulation is an effective strategy to enhance the biodegradation process (Margesin et al., 2007). The potential use of organic wastes derived from plants and animals have been investigated by few researchers. Such wastes include rice husk and coconut shell (Nyankanga et al., 2012), plantain peels and cocoa pod husk (Agbor et al., 2012), Moringa oleifera and soya beans (Danjuma et al., 2012) and animal organic wastes like cow dung, pig dung, poultry manure and goat dung (Yakubu, 2007; Adesodun and Mbagwu, 2008; Agarry et al., 2010; Agarry and Ogunleye, 2012) as biostimulation strategies for petroleum hydrocarbon biodegradation in polluted environments. However, cost effective methods and environmentally friendly strategies of enhancing petroleum hydrocarbon biodegradation in soil necessitated this study.

\section{MATERIALS AND METHODS}

Samples Collection, Preparation and Experimental Design: Goat dung was collected from Goat Unit, Teaching and Research Farm, Federal University of Agriculture Abeokuta (FUNAAB), Nigeria. The manure was air dried, ground, mixed, sieved with a 2 $\mathrm{mm}$ sieve and stored in polythene bag.

Top soil ( $0-15 \mathrm{~cm}$ depth) was collected from Nigerian National Petroleum Corporation Satellite Depot, 
Ejigbo, Lagos State using a soil auger. The soil was air dried in a clean, well ventilated laboratory, homogenized by crushing and sieved by passing through a $2 \mathrm{~mm}$ mesh sieve. One kilogram of soil was measured into nine clean dry containers of three litres each.

Goat dung was applied at the rate of 0 (control), 50 and $100 \mathrm{~g} \mathrm{~kg}^{-1}$ soil in triplicate. The goat dung was thoroughly mixed with the soil and the nine containers were arranged in a Completely Randomized Design in a greenhouse. Soil samples were taken from each container at 21 and 42 days for $\mathrm{pH}$, organic carbon, nitrogen, phosphorus, potassium, hydrocarbon degrading bacteria count, hydrocarbon utilizing bacteria and polycyclic aromatic hydrocarbon determination.

Soil Chemical Properties: The $\mathrm{pH}$, organic carbon, total nitrogen, potassium and available phosphorus were determined in the soil samples using the methods described by Chopra and Kanwar (2011).

Cultural Characterization of Bacteria: Pure cultures of representative bacteria colonies were randomly picked from inoculated plates and were grouped on the basis of their colonial characteristics such as colony elevation, colour, size, opacity, shape, consistency, and edge (Barnett and Hunter, 1985).

Morphological Characterization of Bacteria: Cultural grouping was followed by microscopic examination of isolates for cellular morphology. Day-old cultures of the bacteria isolates were stained with cotton blue lacto-phenol blue and observed microscopically for cell shape, size and sporulation (Barnett and Hunter, 1985).

Biochemical Characterization of Bacteria: A modified method of Cheesbrough (2006) was used for Gram staining, catalase test, urease test, citrate utilization test, indole test, motility test, coagulase test and sugar fermentation test.

Determination of Total Hydrocarbon Utilizing Bacteria Count: Total hydrocarbon utilizing bacteria count was carried out on mineral salt medium (MSM) agar as described by Balogun and Fagade (2010); and the isolated microorganisms were identified using Bergey's manual of systemic bacteriology (Krieg and Holt, 1984).

Determination of Polycyclic Aromatic Hydrocarbon: Ten grams of the petroleum products polluted soil sample was weighed into a clean bottle and $25 \mathrm{ml}$ of dichloromethane was added, the mixture was allowed to stand on a mechanical shaker for a period of 3- 4 hours. The procedure was repeated twice and the aliquots were collected and mixed together in a beaker. The aliquots were concentrated on a steam bath reducing the extracts to about $5 \mathrm{ml}$. The concentrate was passed through a pipette packed with anhydrous sodium sulphate on top of a glass wool to remove moisture and other impurities. The final extract was analysed using a Hewlett-Packard 5890 series GC system coupled to a mass spectrophotometer $\mathrm{VG}$ TRIO 2000 to determine the quantity of total petroleum hydrocarbons.

The degradation of petroleum products was expressed as the percentage of petroleum products degraded in relation to the amount of the remaining fractions in the appropriate abiotic control samples (Equation 1). The biodegradation efficiency (BE) based on the decrease in the total concentration of hydrocarbons, was calculated using Equation 1 (Mohan et al., 2006).

$B E=100-\left(\frac{A s \times 100}{A a c}\right) \ldots \ldots \ldots \ldots 1$

Where As $=$ total area of peaks in each sample, Aac $=$ total area of peaks in the appropriate abiotic control and $\mathrm{BE}(\%)=$ biodegradation efficiency.

Statistical Analysis: Data obtained were subjected to descriptive (mean and standard deviation) and inferential (ANOVA) statistics. Means were separated using Duncan Multiple Range Test (DMRT). Statistical Analysis System (SAS) software version 9.0 portable was used.

\section{RESULTS AND DISCUSSION}

Chemical Properties of Soils and Pig Dung: The soil $\mathrm{pH}$, total nitrogen $(\mathrm{N})$, available phosphorous $(\mathrm{P})$, exchangeable potassium (K), Organic Carbon (OC) and Polycyclic Aromatic Hydrocarbon (PAH) before GD application were shown in Table 1.

Table 1: Chemical Properties of the Polluted Soil prior to Goat

\begin{tabular}{ll}
\multicolumn{2}{c}{ Dung Application } \\
\hline Parameters & Polluted soil \\
\hline $\mathrm{pH}$ & $6.70 \pm 0.11$ \\
Nitrogen $\left(\mathrm{g} \mathrm{kg}^{-1}\right)$ & $1.21 \pm 0.21$ \\
Available phosphorus $\left(\mathrm{mg} \mathrm{kg}^{-1}\right)$ & $29.25 \pm 2.59$ \\
Exchangeable potassium $\left(\mathrm{Cmol} \mathrm{kg}^{-1}\right)$ & $0.31 \pm 0.11$ \\
Organic Carbon $\left(\mathrm{g} \mathrm{kg}^{-1}\right)$ & $55.89 \pm 3.56$ \\
THDB $\left(\mathrm{cfu} \mathrm{g}^{-1}\right)$ & $2.23 \times 10^{4} \pm 1.87 .00 \times 10^{2}$ \\
PAH $\left(\mathrm{mg} \mathrm{kg}^{-1}\right)$ & $192.65 \pm 1.22$ \\
\hline \multicolumn{2}{c}{ Values are means $\pm S D$ of three replicates. }
\end{tabular}

The polycyclic aromatic hydrocarbons (PAH) compounds detected in the soil before goat dung application were sixteen (Table 2). The goat dung used in this study was high in organic carbon $(47.86 \pm 2.37 \mathrm{~g}$ 
$\mathrm{kg}^{-1}$ ) and also contained total hydrocarbon-degrading bacteria of $7.35 \times 10^{3} \pm 1.87 \times 10^{3} \mathrm{CFU} \mathrm{g}^{-1}$ while the polycyclic aromatic hydrocarbon compounds were below detection limit (Table 3).

Table 2: Concentration of Polycyclic Aromatic Hydrocarbon Compounds in the Polluted Soil before Amendment

\begin{tabular}{lll}
\hline $\mathrm{S} / \mathrm{N}$ & Compounds & Concentration $\left(\mathrm{mgkg}^{-1}\right)$ \\
\hline 1 & Naphthalene & $1.58 \pm 0.42$ \\
2 & Acenaphthylene & $2.07 \pm 0.36$ \\
3 & Acenaphthene & $1.96 \pm 0.22$ \\
4 & Fluorene & $1.84 \pm 0.17$ \\
5 & Phenanthrene & $7.04 \pm 1.26$ \\
6 & Anthracene & $20.15 \pm 2.83$ \\
7 & Fluoranthene & $29.82 \pm 3.77$ \\
8 & Pyrene & $26.51 \pm 2.88$ \\
9 & Benzo(a)anthracene & $34.18 \pm 3.12$ \\
10 & Benzo(b)fluoranthene & $16.34 \pm 1.82$ \\
11 & Chrysene & $9.07 \pm 1.23$ \\
12 & Benzo(k)fluoranthene & $10.82 \pm 1.24$ \\
13 & Benzo(a)pyrene & $9.50 \pm 1.29$ \\
14 & Indeno(1,2,3,cd)pyrene & $12.87 \pm 1.36$ \\
15 & Dibenz(a,h)anthracene & $6.32 \pm 1.44$ \\
16 & Benzo(g,h,I)perylene & $4.56 \pm 0.66$ \\
\hline & Values are means \pm SD of three replicates.
\end{tabular}

Effect of Goat Dung Application on the Soil Chemical Properties: Application of goat dung significantly ( $\mathrm{p}$ $<0.05$ ) increased $\mathrm{pH}$ of the contaminated soil compared to the control (without goat dung application) at 21 and 42 days (Table 3). The $\mathrm{pH}$ of soil before goat dung application was $7.90 \pm 0.10$ while control, 50 and $100 \mathrm{~g}$ of goat dung were $6.8 \pm 0.06$ and $6.7 \pm 0.20 ; 7.3 \pm 0.10$ and $7.2 \pm 0.06 ; 7.4 \pm 0.15$ and $7.2 \pm 0.06$ for day 21 and 42 respectively indicating a downward trend.

Table 3: Proximate Analysis of the Goat Dung

\begin{tabular}{ll}
\hline Parameters & Cow dung \\
\hline $\mathrm{pH}$ & $6.70 \pm 0.20$ \\
Nitrogen $\left(\mathrm{g} \mathrm{kg}^{-1}\right)$ & $17.27 \pm 1.20$ \\
Phosphorus $\left(\mathrm{mg} \mathrm{kg}^{-1}\right)$ & $1.10 \pm 0.11$ \\
Potassium $\left(\mathrm{Cmol} \mathrm{kg}^{-1}\right)$ & $0.22 \pm 0.11$ \\
Organic Carbon $\left(\mathrm{g} \mathrm{kg}^{-1}\right)$ & $47.86 \pm 2.37$ \\
THDB $(\mathrm{CFU} \mathrm{g-}-1$ & $7.35 \times 10^{3} \pm 1.87 \times 10^{3}$ \\
PAH $\left(\mathrm{mg} \mathrm{kg}^{-1}\right)$ & BDL \\
\hline \multicolumn{2}{c}{ Values are means $\pm S D$ of three replicates }
\end{tabular}

Total $\mathrm{N}$ of the soil $\left(\mathrm{g} \mathrm{kg}^{-1}\right)$ before goat dung application was 1.92 while control, 50 and $100 \mathrm{~g}$ of goat dung were $0.69 \pm 0.21$ and $0.42 \pm 0.31,1.19 \pm$ 0.10 and $0.86 \pm 0.30,2.11 \pm 0.10$ and $2.11 \pm 0.10$ for 21 and 42 days respectively indicating a downward trend for the experimental. Significantly $(\mathrm{p}<0.05)$ lower $\mathrm{N}, \mathrm{P}, \mathrm{K}$ and organic carbon was observed in 50 and $100 \mathrm{~g}$ goat dung $\mathrm{kg}^{1}{ }^{1}$ soil at 21 and 42 days respectively.

Table 4: Effects of Goat Dung Amendment on the Soil Chemical Properties

\begin{tabular}{lllllll}
\hline \multicolumn{7}{c}{ Table 4: Effects of Goat Dung Amendment on the Soil Chemical Properties } \\
$\begin{array}{l}\text { Goat dung } \\
\text { level }(\mathrm{g})\end{array}$ & DDA & $\mathrm{pH}$ & $\begin{array}{l}\text { Nitrogen } \\
\left(\mathrm{g} \mathrm{kg}^{-1}\right)\end{array}$ & $\begin{array}{l}\text { Phosphorus } \\
\left(\mathrm{mg} \mathrm{kg}^{-1}\right)\end{array}$ & $\begin{array}{l}\text { Potassium } \\
\left(\mathrm{Cmol} \mathrm{kg}^{-1)}\right.\end{array}$ & $\begin{array}{l}\text { Organic carbon } \\
\left(\mathrm{g} \mathrm{kg}^{-1}\right)\end{array}$ \\
\hline 0 & 21 & $6.8 \pm 0.1^{\mathrm{bb}}$ & $0.69 \pm 0.21^{\mathrm{e}}$ & $60.11 \pm 2.10^{\mathrm{e}}$ & $0.28 \pm 0.06^{\mathrm{cc}}$ & $32.24 \pm 0.59^{\mathrm{c}}$ \\
& 42 & $6.7 \pm 0.1^{\mathrm{b}}$ & $0.42 \pm 0.31^{\mathrm{f}}$ & $47.23 \pm 2.14^{\mathrm{f}}$ & $0.15 \pm 0.10^{\mathrm{c}}$ & $27.02 \pm 1.22^{\mathrm{d}}$ \\
50 & 21 & $7.2 \pm 0.10^{\mathrm{aa}}$ & $1.19 \pm 0.10^{\mathrm{c}}$ & $134.15 \pm 4.11^{\mathrm{c}}$ & $1.11 \pm 0.02^{\mathrm{bb}}$ & $40.28 \pm 3.11^{\mathrm{b}}$ \\
& 42 & $7.1 \pm 0.2^{\mathrm{a}}$ & $0.86 \pm 0.30^{\mathrm{d}}$ & $109.22 \pm 1.27^{\mathrm{d}}$ & $0.72 \pm 0.23^{\mathrm{b}}$ & $32.36 \pm 0.11^{\mathrm{cc}}$ \\
100 & 21 & $7.2 \pm 0.1^{\mathrm{aa}}$ & $2.11 \pm 0.10^{\mathrm{a}}$ & $198.56 \pm 5.33^{\mathrm{a}}$ & $1.13 \pm 0.04^{\mathrm{a}}$ & $52.10 \pm 3.76^{\mathrm{a}}$ \\
& 42 & $7.1 \pm 0.2^{\mathrm{aa}}$ & $1.07 \pm 0.05^{\mathrm{b}}$ & $145.12 \pm 4.56^{\mathrm{b}}$ & $1.11 \pm 0.05^{\mathrm{bb}}$ & $38.22 \pm 2.14^{\mathrm{cc}}$ \\
\hline
\end{tabular}

Values are means \pm SD of three replicates. Different superscript in the same column indicate significant difference at $p<0.05$ (DMRT), DDA-Days after amendment

Effect of Goat Dung on the Hydrocarbon Degrading Bacteria Counts and Identification: The values of total hydrocarbon degrading bacteria decreased from 21 to

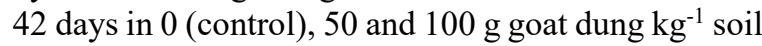
(Table 5). The total hydrocarbon degrading bacteria were found to be higher in soil amended with goat dung than the control soil. Morphological characteristics of bacteria isolated from the polluted soil amended with Goat dung at 42 days are presented in Table 6.

The size of the bacteria ranged between $1-5 \mathrm{~mm}$. Most of the bacteria were irregular in shape, greywhite in colour, wet consistency, smooth edges, flat elevation and opaque.

The types and relative abundance of microbial communities in microcosms due to natural attenuation and biostimulation treatment methods observed in the contaminated soil are presented in Table 7. Six hydrocarbon degrading bacteria were identified from the polluted soil. The hydrocarbon degrading bacteria identified belong to the genera Bacillus, Staphylococcus, Klebsiella, Escherichia, Pseudomonas and Enterobacter. Bacillus species were the most predominantly isolated bacterial species.

Table 5: Total Hydrocarbon Degrading Bacteria Count of the Polluted Soil Amended with Goat Dung

\begin{tabular}{lll}
\hline Goat dung level & DDA & THDB $\left(\mathrm{CFU} \mathrm{g}^{-1}\right)$ \\
\hline 0 & 21 & $1.10 \times 10^{4} \pm 2.00 \times 10^{2 \mathrm{~d}}$ \\
& 42 & $0.97 \times 10^{4} \pm 4.00 \times 10^{2 \mathrm{e}}$ \\
50 & 21 & $1.38 \times 10^{4} \pm 2.00 \times 10^{2 \mathrm{c}}$ \\
& 42 & $1.10 \times 10^{4} \pm 3.00 \times 10^{2 \mathrm{~cd}}$ \\
100 & 21 & $2.14 \times 10^{4} \pm 5.00 \times 10^{2 \mathrm{a}}$ \\
& 42 & $1.37 \times 10^{4} \pm 3.00 \times 10^{2 \mathrm{~b}}$ \\
\hline
\end{tabular}

Values are means $\pm S D$ of three replicates. Different superscript in the same column indicate significant difference at $p<0.05$ (DMRT); DDA-Days after amendment 
Table 6: Morphological Characteristics of Bacteria Isolated from the Polluted Soil

\begin{tabular}{llllllll}
\hline $\begin{array}{l}\text { Isolate } \\
\text { Code }\end{array}$ & $\begin{array}{l}\text { Size } \\
(\mathrm{mm})\end{array}$ & Shape & Colour & Consistency & Edges & Elevation & Opacity \\
\hline 0 g GD & $2-3$ & Irregular & Grey-white & Wet & Rough & Raised & Opaque \\
& $3-4$ & Smooth & Yellow & Dry & Smooth & Slightly raised & Opaque \\
& $3-4$ & Round & Grey-white & Wet & Rough & Flat & Opaque \\
50 g GD & $3-5$ & Round & White & Wet & Smooth & Flat & Opaque \\
& $1-2$ & Irregular & Green & Wet & Smooth & Raised & Opaque \\
& $3-4$ & Round & Grey-white & Wet & Smooth & Raised & Opaque \\
100 g GD & $1-2$ & Round & White & Dry & Rough & Flat & Opaque \\
& $3-5$ & Smooth & Yellow & Wet & Smooth & Flat & Opaque \\
& $3-4$ & Irregular & Grey-white & Wet & Smooth & Flat & Opaque \\
\hline
\end{tabular}

Table 7: Types and relative abundance of micro-organisms in the polluted soil

\begin{tabular}{|c|c|c|c|c|c|c|c|c|c|c|c|c|c|c|c|c|}
\hline Isolate code & GR & SP & $\begin{array}{l}\mathrm{C} \\
\mathrm{P}\end{array}$ & $\begin{array}{l}\mathrm{C} \\
\mathrm{A}\end{array}$ & $\mathrm{CO}$ & $\begin{array}{l}\mathrm{M} \\
\mathrm{O}\end{array}$ & $\mathrm{IN}$ & $\begin{array}{l}\mathrm{O} \\
\mathrm{X}\end{array}$ & CI & $\begin{array}{l}\mathrm{U} \\
\mathrm{R}\end{array}$ & $\begin{array}{l}\mathrm{M} \\
\mathrm{R}\end{array}$ & $\begin{array}{l}\mathrm{V} \\
\mathrm{P}\end{array}$ & G & $\mathrm{L}$ & M & $\begin{array}{l}\text { Probable } \\
\text { organism }\end{array}$ \\
\hline \multirow[t]{3}{*}{$0 \mathrm{~g} \mathrm{GD}$} & GPB & + & + & + & - & + & - & - & - & - & + & - & $\mathrm{A}$ & - & - & Bacillus subtilis \\
\hline & GPB & + & + & + & - & + & - & - & - & - & + & _ & A & - & - & Bacillus subtilis \\
\hline & GNB & - & - & + & - & + & - & - & + & - & + & - & A & $\mathrm{A}$ & - & Enterobacter sp \\
\hline \multirow[t]{3}{*}{$50 \mathrm{~g} \mathrm{GD}$} & GNB & - & - & + & - & + & + & - & - & - & + & - & A & A & - & Escherichia coli \\
\hline & GNB & - & - & + & - & + & - & + & + & - & + & - & - & - & - & $\begin{array}{l}\text { Pseudomonas } \\
\text { aeruginosa }\end{array}$ \\
\hline & GNB & - & - & + & - & - & - & - & + & + & - & + & A & A & - & Klebsiella sp. \\
\hline \multirow[t]{3}{*}{$100 \mathrm{~g} \mathrm{GD}$} & GPB & + & + & + & - & + & - & - & - & - & + & - & A & A & - & Bacillus Subtilis \\
\hline & GPC & - & - & + & + & - & - & - & - & - & - & + & A & A & A & Staph. aureus \\
\hline & GPB & + & + & + & - & + & - & - & - & - & + & - & $\mathrm{A}$ & - & - & Bacillus subtilis \\
\hline
\end{tabular}

Keys : GR-Gram staining, SP-spore staining, CA-Capsule staining, CT-Catalase, MO-Motility, IN-Indole, OX- Oxidase, CI-Citrate, INIndole, OX-Oxidase, CI-citrate, UR-Urea, MR-Methyl-red, VP-Vogesproskeur, G-Glucose, L-lactose, S-Sucrose, M-Mannitol, A-Acid production, $C D=$ cow dung, $g=$ gram, $-=$ Absent, $+=$ Present, $A=$ Abundant

Table 8: Rate of Change of Polycyclic Aromatic Hydrocarbon during Biodegradation of the Polluted oil

\begin{tabular}{cclll}
\multicolumn{5}{c}{ during Biodegradation of the Polluted oil } \\
\hline $\begin{array}{l}\text { Goat } \\
\text { dung } \\
\text { level } \\
(\mathrm{g})\end{array}$ & DAA & $\begin{array}{l}\text { PAH } \\
\left(\mathrm{mg} \mathrm{kg}^{-1}\right)\end{array}$ & $\begin{array}{l}\text { PAH } \\
\text { Degraded } \\
\left(\mathrm{mg} \mathrm{kg}^{-1}\right)\end{array}$ & $\begin{array}{l}\text { Degradation } \\
(\%)\end{array}$ \\
\hline 0 & 21 & $167.32 \pm 1.71^{\mathrm{a}}$ & 25.33 & 13.15 \\
& 42 & $134.26 \pm 1.59^{\mathrm{b}}$ & 58.39 & 30.31 \\
50 & 21 & $107.11 \pm 1.88^{\mathrm{c}}$ & 85.54 & 44.40 \\
& 42 & $74.16 \pm 2.27^{\mathrm{d}}$ & 118.49 & 61.50 \\
100 & 21 & $75.10 \pm 3.65^{\mathrm{e}}$ & 117.55 & 61.01 \\
& 42 & $46.14 \pm 1.93^{\mathrm{f}}$ & 146.51 & 76.05 \\
\hline
\end{tabular}

Values are means $\pm S D$ of three replicates. Different superscript in the same column indicate significant difference at $p<0.05$

(DMRT); DDA-Days after amendment

Effects of Goat Dung on Polycyclic Aromatic Hydrocarbon in the polluted Soil: At $42^{\text {nd }}$ day after goat dung amendment, $146.51 \mathrm{mg} \mathrm{kg}^{-1}(76.05 \%)$ reduction in polycyclic aromatic hydrocarbon was observed at $100 \mathrm{~g} \mathrm{~kg}^{-1}$ of GD while $118.49 \mathrm{mg} \mathrm{kg}^{-1}$ $(61.50 \%)$ reduction in polycyclic aromatic hydrocarbon was observed at $50 \mathrm{~g} \mathrm{~kg}^{-1}$ of GD from an initial concentration of $192.65 \mathrm{mg} \mathrm{kg}^{-1}$. The polycyclic aromatic hydrocarbon concentrations decreased from 21 to 42 days (Table 8).

Biodegradation increased significantly $(\mathrm{p}<0.05)$ within the first three weeks with $117.55 \mathrm{mg} \mathrm{kg}^{-1}(61.01$ $\%)$ reduction in polycyclic aromatic hydrocarbon at $100 \mathrm{gkg}^{-1}$ of GD and $85.54 \mathrm{mg} \mathrm{kg}^{-1}(44.40 \%)$ reduction in polycyclic aromatic hydrocarbon at $50 \mathrm{gkg}^{-1}$ of GD (Table 8). In the control soil, $25.33 \mathrm{mg} \mathrm{kg}^{-1}(13.15 \%)$ reduction in polycyclic aromatic hydrocarbon was observed in the first three weeks while $58.39 \mathrm{mg} \mathrm{kg}^{-}$ ${ }^{1}(30.31 \%)$ reduction was observed on the sixth week (forty second day). The polycyclic aromatic hydrocarbon concentrations decreased from 21 to 42 days. This study was carried out to determine the effects of Goat Dung (GD) on Polycyclic Aromatic Hydrocarbon (PAH) degradation and microbiological composition. There was significantly $(\mathrm{p}<0.05)$ increase in $\mathrm{pH}$ on application of GD to the polluted soils compared to the control at 21 and 42 days. In an experiment conducted by Vidali and Yakubu (2001), they observed that a $\mathrm{pH}$ range between 6.9 and 7.5 is good for most hydrocarbon degrading bacteria. In this study, there was gradual decrease in $\mathrm{pH}$ as biodegradation progressed. This decrease was connected to the biodegradation process which removed the contaminant and introduced some salts and ions from goat dung (Akpoveta et al., 2011). The decrease in soil N, P, K and organic carbon content from 21 to 42 days at every goat dung level might be due to their high demand by microorganisms for sugar phosphorylation, nucleic acid synthesis and other cellular processes (Andrew and Jackson, 1996). It has been reported that petroleum hydrocarbon contaminants could destroy inorganic nutrient sources by reacting with them along with other substances present in soil (Teal et al., 1992; Andrew and Jackson, 1996). There was reduction in population of total hydrocarbon degrading bacteria from 21 to 42 days in 
0 (control), 50 and $100 \mathrm{~g}$ cow dung $\mathrm{kg}^{-1}$ soil. This reduction in population of total hydrocarbon degrading bacteria was connected to the fact that mineralization of hydrocarbons could have possibly resulted in the production of toxic metabolites which on introduction into the system reduces the growth phase of the microbes (Akpoveta et al., 2011). Microorganisms generally require mineral nutrients sources for growth (Andrew and Jackson, 1996). If any of the required nutrients is lacking or becomes limiting, particularly the macro-mineral elements, microbial population will decrease (Giordani et al., 1998; Lehtola et al., 1998; Vidali, 2001). Akpoveta et al. (2011) also reported a decline in bacterial population as the biodegradation progressed. In this study, Bacillus species were the most predominant isolated bacterial species. Its prevalence could be attributed to the fact that it forms spores, which help microorganisms to withstand harsh conditions. Isolation of Bacillus species from hydrocarbon contaminated soil amended with goat dung could also be attributed to its ubiquitous distribution in nature. Mansour et al. (1999) reported the isolation of Bacillus, Acinetobacter, Staphylococcus and Enterobacter among other bacteria from hydrocarbon contaminated soil. The oil degrading bacteria isolated from this study have previously been implicated in hydrocarbon biodegradation, though from different sources (Ijah and Antai, 2003; Yakubu, 2007).

Degradation of polycyclic aromatic hydrocarbon in the contaminated soil amended with goat dung might be due to the bacterial consortium in the goat dung that attacked and degraded the components of the hydrocarbon (Yakubu, 2007; Adesodun and Mbagwu 2008). Significantly $(p<0.05)$ higher concentration of polycyclic aromatic hydrocarbon was observed in the soil without goat dung amendment. Biostimulation has been reported as an important factor that enhance soil bioremediation (Cardona and Iturbe, 2003; Gallego et al., 2010). Egbeja et al. (2019) in their study of in situ bioremediation techniques reported that it is possible to degrade up to $99 \%$ of hydrocarbon pollutant, during biostimulation.

Conclusion: This study determined the effects of GD on Polycyclic Aromatic Hydrocarbon (PAH) degradation and microbiological composition. After 42 days of incubation, approximately $76 \%$ of PAH removal was observed in microcosms with $100 \mathrm{~g} \mathrm{~kg}$ ${ }^{1}$ of GD compared to only $30 \%$ of PAH removal in microcosms without amendments. Results indicate that GD is effective in hydrocarbon biodegradation when conditions such as $\mathrm{pH}$ requirement and nutrient availability are taken into consideration.

\section{REFERENCES}

Adesodun, J K; Mbagwu, JSC (2008). Biodegradation of waste-lubricating petroleum oil in a tropical alfisol as mediated by animal droppings. Biores. Technol. 99 (13): 5659-5665.

Agarry, SE, Owabor, CN; Yusuf, RO (2010). Studies on biodegradation of kerosene in soil under different bioremediation strategies. Biorem. J. 14 (3): $135-141$.

Agarry, SE; Ogunleye, OO (2012). Box-behnken designs application to study enhanced bioremediation of soil artificially contaminated with spent engine oil using biostimulation strategy. Inter. J. Energy. Environ. Engineer. 3: $31-34$.

Agbor, RB; Ekpo, IA, Osuagwu, AN; Udofia, UU; Okpako, EC; and Antai, SP (2012). Biostimulation of microbial degradation of crude oil polluted soil using cocoa pod husk and plantain peels. J. Microbiol. Biotechnol. Res. 2 (3): 464-469

Akpoveta, OV; Egharevba, F; Medjor, OW; Osaro, KI; Enyemike, ED (2011). Microbial degradation and its kinetics on crude oil polluted soil. Res. eJ. Chem. Sci. 1(6): 8-14.

Alexander, M (2000). Aging, bioavailability and overestimation of risk from environmental pollutants. Environ. Sci. Technol. 34: 4259-4265.

Andrew, RWJ; Jackson JM (1996). Environmental science: the natural environment and human impact. Longman Publishers, Singapore.

Balogun SA; Fagade, OE (2010). Emulsifying bacteria in produce water from Niger-Delta, Nigeria. Afri. J. Microbiol. Res. 4(9): 730-734.

Barnett, HI; Hunter BB (1985). Illustrated genera of imperfect fungi. $5^{\text {th }}$ edition. Burges Publishing Company. Minnesota.

Cardona, S; Iturbe R (2003). Biodegradación de diesel mexicanoporunconsorcio de bacterias de un sueloagrícola, 138: 13-26.

Cheesbrough, M (2006). District Laboratory Practice in Tropical Countries.Part 1 ( $2^{\text {nd }}$ edition), Cambridge University Press,UK, pp.143-157 
Chopra, S L; Kanwar, JS (2011). Analytical Agricultural Chemistry. Kalyani publishers: New Delhi, 152 - 195.

Danjuma, BY; Abdulsalam, S; Sulaiman, AD I (2012). Kinetic investigation of Escravos crude oil contaminated soil using natural stimulants of plant sources. Inter. J. Emerging Trends in Engineer. Develop. 2 (5): 478-486.

Egbeja, TI; Bada, BS; Arowolo, TA; Obuotor, TM (2019). Microbial degradation of an oil polluted site in abule-egba, Nigeria. Ife J. Sci. 21(2):299308

Gallego, JR; Loredo, J; Llamas, JF; Vazquez, F; Sanchez, J (2010). Bioremediation of dieselcontaminated soils: evaluation of potential in situ techniques by study of bacterial degradation. Biodegradation. 12: 325-335.

Giordani, G; Donnelly, A; Azzoni R (1998). The uptake of inorganic phosphate by Z. Noltii in the Basin d' Arcachon. In: Proceedings (Handbook) of Summer Conference of the Society for Applied Microbiology, University of Lancaster, UK, 2223.

Ijah, UJ; Antai, SP (2003). The potential use of Chicken-drop microorganisms for oil spill remediation. The Environmentalist. 23:89-95.

Krieg, NR; Holt, JG (1984). Bergey's Manual of Systematic Bacteriology. 1 Baltimore, Williams and Wilkins, Washington, USA.

Lehtola, M; Miettinen, I; Vartianen, T; Martikainen, PJ (1998). Purification of drinking water phosphorus and bacterial growth. In: Proceedings (Handbook) of Summer Conference of the Society for Applied Microbiology, University of Lancaster, UK), 16-17
Margesin, R; Hammerle, M; Tscherko, D (2007). Microbial activity and community composition during bioremediation of diesel-oil-contaminated soil: Effects of hydrocarbon concentration, fertilizers, and incubation time. Microbial Ecology, 53: 259 - 269.

Mansour, M; Bottefroy, D; Linder A (1999). Inhibition of Bacillus lincheniformis spore growth in milk by nisin, monolaurin, and $\mathrm{pH}$ combinations. Journal of Applied Microbiology, 86: 311-324.

Mohan, SV; Kisa, T; Ohkuma, T; Kanaly, RA; Shimizu, Y (2006). Bioremediation technologies for treatment of PAH contaminated soil and strategies to enhance process efficiency. Rev. Environ. Sci. Biotechnol. 5(4): 347-374.

Nyankanga, RO; Onwonga, RN; Wekesa, FS; Nakimbugwe D; Masinde, D (2012). Effect of inorganic and Organic Fertilizers on the performance and profitability of Grain Amaranth (Amaranthuscaudatus L.) in Western Kenya. $J$. Agric. Sci. 4: 223-232.

Teal, JM; Farrington, JW; Burns, KA; Stegeman, JJ; Tripp BW; Woodin B; Phinnley C (1992). The West Faimouth oil spill after 20 years; fate of fuel oil compounds and effects on animals. Mar. Pollute. Bull. 24: 607614.

Vidali, M (2001). Bioremediation: An overview. $J$. Appl. Chem. 73 (7):1163-1172.

Yakubu, MB (2007). Biodegradation of Lagoma crude oil using pig dung. Afr. J. Biotechnol. 6: 2821-2825. 